\title{
Değerlendirme/Publication Review
}

\section{ABAY KUNANBAYULI - KITÂB-I'AKLIYYE'}

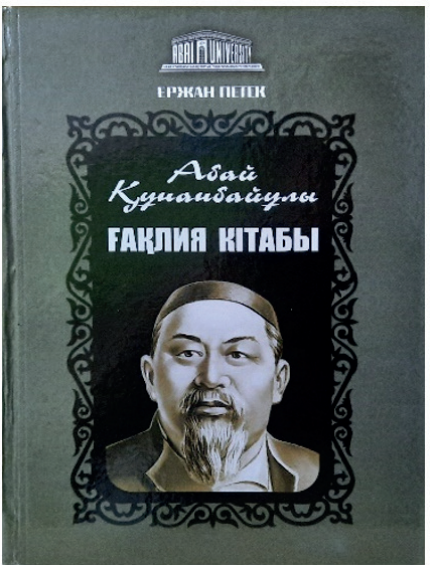

Marlen ADILOV*

Bugüne kadar Kazakistan'da Abay eserleri üzerine pek çok çalışma yapılmış olmakla birlikte el yazması metin üzerinden transkripsiyonu ve indeksi eksiksiz olarak hazırlanmış bir çalışma henüz yapılmamıştır. Abay'a ait mevcut eserlerin hepsi okurlar için üzerinde oynanmış, çağdaş Kazak dili normlarına göre değişiklikler yapılmış metinlerdir. $\mathrm{Bu}$ açıdan bakıldığında Abay şiirleri ile kara sözlerini çağdaş Kazak dilinin gramer özelliklerine göre hazırlamak yerinde bir iştir. Abay'ın eserlerini bütün okuyucuların anlayabileceği bir formda hazırlayıp sunmak ne kadar gerekliyse onun el yazmasını da araştırmacılarla buluşturmak bir o kadar önemlidir. Çünkü Abay dili üzerine araştırma yapanların el yazması metinler üzerinden çalışmaları değer arz ediyor. Çağdaş Kazak dili gramer kaidelerine göre hazırlanıp üzerinde oynanmış metinlere göre üzerinde herhangi bir değişiklik yapılmamış el yazması metinlerin dil açısından daha çok malzeme sunacağı bir gerçektir. 
Çalışmada Abay'ın Kara Sözler'inin11 1907 y1lında Murseyit Bikeulı'nın Arap harfleriyle yazıya geçirdiği nüshası verilmiş̦tir. Arap harfleriyle yazılan kara sözlere ait el yazması tekrar okunup onun yeni bir transkripsiyonu yapılmıştır. Çalışmada el yazması metnin gramatikal indeksi de hazırlanmıştır. Bununla birlikte bu araştırmada çağdaş Kazak dilinden ayrılan fonetik ve morfolojik özellikler ile leksik kullanımlar hakkında bilgiler verilmiştir.

Abay'ın eserleri üzerine yapılan ilmî çalışmalarda Abay'a özgü özelliklerin doğru gösterilebilmesi için imla özelliklerinin mümkün olduğunca eksiksiz verilmesi gerekir. Ancak Abay eserleri üzerine yapılan çalışmaların büyük bölümünde değiş̧iklikler yapılıp çağdaş dil normlarına göre çıkarılmaktadır. Bu çalışmanın en önemli özelliği ise metnin üzerinde oynama yapılmadan olduğu gibi verilmiş olmasıdır. Mesela kaygu $+g a, k a y s u+s l$, ketür $+e r$, ötrik $+d i$, adamdlk+dın, bergen+nün vb. Oysa bunlar Kazak edebî dilinde kaygl+ga "derde", kaysı+sl "hangisi", ketir+er/äkel+er "getirir", ötirik+ti "yalanı", adamdik+tıñ "insanlı̆̆ın", bergen+nün "verenin" vb. Bu sebeple elinizdeki çalışma Abay'ın dilini doğrudan el yazması metin üzerinden araştırmak isteyen dil uzmanları için oldukça kıymetlidir.

Kara Sözler Arap harfleriyle ve edebî dil olan Çağatay Türkçesi temelinde yazıldığından dönemin dil özelliklerini görmek mümkündür. Abay'ın Kara Sözler'ini yazıya geçiren hemşehrisi Mürseyit Bikeulı'nın (1860-1917) Abay'ın eserlerinin bugünkü nesle ulaşmasında emeği büyüktür. Abay, Murseyit'i yanına aldırarak ona eserlerini yazıya geçirme görevi vermiştir. Bu sebeple akının eserleri bize Murseyit aracılığıyla yazılı olarak ulaşmaktadır. Murseyit yazıya geçirdiği şiirleri ve Kara Sözler'i Abay'ın ölümünden sonra baskıya vermiştir. Bu yazmalardan biri de 1907 tarihli yazmadır. Günümüzde Murseyit'e ait el yazması metinler Abay eserlerinin en önemli nüshalarıdır. Bugün büyük bir okur kitlesi tarafindan tanınan şiirler ile kara sözlerin tamamı Murseyit defterlerinden alınmıştır. Tek kaynak budur. Çünkü doğrudan Abay tarafından kaleme alınmış yazma yok denecek kadar azdır. Mürseyit hoca, kara sözlerin içeriğine noksan getirmese de bazı sözleri Çağatay ya da Arap dilindeki orijinal formuyla kayda geçirmiş gibidir. Dönemin yazı dili geleneğini iyi bilen Murseyit, Abay'ın kullandığı Arapça sözleri edebî dil normlarına göre yazmış olmalıdır. Böyle düşünmemizin sebebi metindeki Arapça kökenli sözlerin tamamının aslına uygun olarak yazılmış olmasıdır. Arap harfleriyle yazılan metindeki kullanışları Çağatay Dili Sözlüğ̈̈'ndeki eş değerleriyle karşılaştırdığımızda Çağataycadaki formlarıyla bire bir örtüştüğü görülmektedir. Örneğin yazmadaki 'adâlet, 'acâib, cem 'iyyet, dâimâ, dûzâh, rûze gibi ke-

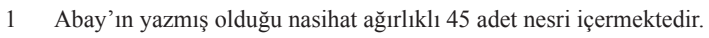


limeler Kazakçada ädilet, gajayıp, jamagat, ärdayım, tozak, oraza olarak yazılmaktadır.

El yazmasında -ç-, -ş- ve $-y$ seslerinin Çağataycadaki gibi korunduğu görülmektedir: çarça-p "yorulup" (31/18), neçük "nasıl" (10/16), bala çaga+ga "çoluk çocuğa" (44/15); işlegenlik+ine "yaptı̆̆ına" (73/18), uhşaş "benzer" (72/3); yukarı+da "yukarıda" (71/14); yırak "ırak" (64/11).

Bazı kelimelerin hem Çağatay Türkçesindeki hem de çağdaş Kazak Türkçesindeki formlarınının bir arada kullanıldıklarını görmek mümkündür: çap- "koşturmak" (7/2) - şab- a ber- (15/9); eşüt-mek "işitmek"(60/3) - esüt-diñ (49/6); işle-gen "yapan" (73/2); iste-p (40/9) yalgan "yalan" (68/15) jalgan (11/1), yoklıg1 "yokşuğu" (70/1) joktıg1 (44/10).

Özellikle el yazmasında Tatar (Kazan) Çağataycasının etkileri de vardır, eserde Türkçe kökenli kelimelerdeki "p" sesinin "f" olarak yazılması dikkat çekicidir: yafrak "yaprak" (62/1), yifek "ipek" (62/6); tofrak "toprak" (20/11); kirfik "kirpik" (30/3).

Yazmada Rusça kelimelerin de Kazakça konuşma dilinde yazıldığııı görmek mümkündür. Çünkü şimdiki nüshalarda Rusça kelimeler orijinal dildeki şekilleriyle verilmektedir, el yazmasında ise onların söylendiği gibi yazıldığı görülmektedir: daznaniye (Rusça ve Abay kitaplarlarında doznaniye) "soruşturma" (3/7); elektriya (Rusça ve Abay kitaplarında эlektr) "elektrik" (67/3); milyon (Rusça ve Kara Sözler' de milliyon) "milyon" (30/1); pasrednik (Abay kitapları ve Rusçada posrednik) "aracı" (5/2); saldat (Rusça ve Abay eserlerinde soldat olarak geçiyor) "asker" (32/10), tragedi "trajedi" (72/15); abrazavaniye (Rusça ve Abay kitaplarında obrazovaniye) "eğitim" (4/5).

Bununla birlikte bugüne kadar Abay eserlerinde bakalşik "tüccar" olarak okunan kelimeyi Ercan Petek buhalçik "içkici" (31/19) diye okumuştur. Bu Rusçanın sokak dilinde kullanılan bir kelimesidir.

Ercan Petek'in kitabının özelliği, bu zamana kadar çağdaş Kazak Türkçesinin kaidelerine göre değiştirilen ve tıpkıbasım metni verilmeyen Abay'ın eserlerinin Türkiye'deki usule göre metin üzerinde herhangi bir değişiklik yapılmadan olduğu gibi verilmesidir. Yukarıda verilen dil bilgisel örneklerin hiçbiri 1945 yılından beri Abay üzerine yapılan çalışmaların baskılarında görülmez. Kazakistan'da Arap harfli metinler üzerine yap1lan çalışmalarda metnin tıpkıbasımı ya da el yazmasının kendisi genellikle verilmez. Bu çalışmada ise Arap harfli el yazması metin kitabın sonuna eklenmiştir. Bu da Türk dünyası ve Abay bilimi, Kazakistan Türkolojisi için büyük katkıdır.

Türkiyeli genç bilim adamı Ercan Petek, Murseyit tarafından yazıya 
geçirilen Abay’ın Kara Sözleri'ne ait el yazması metni dikkatle okuyup eserdeki dil yapılarını tetkik etti. İlk bölümde 15-18. yy.lar arasında yaşayan Kazak akınlarının 20. yy.ın başında yazıya geçirilen Arap harfli nüshaları ile geç dönem Çağatay Türkçesiyle kaleme alınan Dîvân-ı Hikmet'in Kökşetav Nüshası, Kara Sözler'in dil özellikleriyle karşılaş̧ırılmıştır. Burada ses uyumu (ünlü-ünsüz), benzeşme, eski (arkaik) eklerin kullanımı gibi konular ele alınmıştır. Daha sonraki bölümde Arap harfleriyle yazılan el yazmasının Kiril alfabesiyle transkripsiyonu yapılmıştır. El yazmada kullanılan Arap harfleri Kiril alfabesindeki karşıllıklarıyla verildi. Kiril alfabesinde olmayan harfler başka sembollerle gösterildi: $\check{c}, m$, з

Çalışmanın en önemli kısmı el yazmasının gramatikal indeksinin eksiksiz verilmiş olmasıdır. İndeks bölümünde kara sözlerin söz varlığı ile bu sözlerden türeyen kelimeler yer almaktadır. Burada bir kelimenin kaç defa kullanıldığını ve nerede geçtiğini görmek mümkündür. Mesela kl yardımcı fiilinin çeşitli kullanılışları şöyle gösterilmiş̧ir: kal 5/15...; kala gör 6/15; klladı 17/11...; kiladilar 68/14; kila almas 67/4; kllatugun 15/2...; kılduk 44/9; kılduñız 72/7; kılganuña 38/10; kilmakga 57/12; kilmaytugunı 41/1; klluñdar 38/11 gibi. Kll- fiilinin Kazak edebî dilinde işlek olmadığını dikkate alacak olursak (et- aktiftir), Abay'da onun Eski Türkçe ve Orta Türkçedeki gibi yaygın olduğunu görürüz.

Kitabın son bölümünde 1907 tarihli metnin tıpkıbasımı yer almaktadır. El yazmasında 44 kara söz bulunmaktadır (Bugünkü kitaplarda 45 kara söz diye geçmektedir). 44 kara sözün üçü ayrı başlıklar altında verilmiştir. İlki "Kitâb-1 Tasdik", ikincisi "Nasihat", üçüncüsü "Sokrat Hakimnin Sözi" başlığı taşımaktadır. Bunlar Abay Kara Sözleri kitabında ise ayrı konulu olarak verilmez; 27., 37., 38. kara sözler olarak geçmektedir.

Çalı̧̧manın özelliği bugüne kadar defalarca çağdaş Kazak Türkçesi gramer kaidelerine göre düzenlenmiş olan Kara Sözler'in aslına uygun olarak okunup tıpkıbasımı ile birlikte verilmiş olmasıdır. Abay'ın dili üzerine yapılan çalışmaların kaliteli ve ispatlanabilir nitelikte olması için el yazmasındaki nüsha üzerinden araştırma yapmak gerektiği açıktır. Elinizdeki bu çalışma sözü edilen nitelikte bir çalışmadır. 